\title{
Effects of Cash, Receivables, and Inventory Turns on the Profitability of Pharmaceutical Companies
}

\author{
Yulia Ayu Hanifah a,1,*, Darno ${ }^{\text {b,2 }}$ \\ ${ }^{\text {a }}$ Fakultas Ekonomi, Universitas Maarif Hasyim Latif, Sidoarjo, Indonesia \\ ${ }^{\mathrm{b}}$ Fakultas Ekonomi, Universitas Maarif Hasyim Latif, Sidoarjo, Indonesia \\ ${ }^{1}$ yulia-ayu-hanifah@student.umaha.ac.id *; ${ }^{2}$ darno@dosen.umaha.ac.id \\ * corresponding author
}

\section{ARTICLE INFO}

\section{Article History}

Received

Revised

Accepted

Keywords

Receivables;

Inventory Turnover;

Profitability

\section{$A B S T R A C T$}

Competition in the business world makes each company increasingly able to improve its performance in order to achieve the company's goals to get the maximum profit so that the company is able to develop and compete with other companies. In this era of globalization, the emergence of new competitors in various industrial sectors of the company can make competition in business from the last few years very tight. So that requires each company to implement a management system in accordance with procedures in order to develop and run their businesses effectively. Theories that will be explained in this research are about Return on assets and Return On equity, and Net profit margin and also Company Value. This study used a non-experimental research type. Non-experimental research is a part of research in which observations can be carried out on a number of variables contained in the research subject reviewed according to the actual conditions without manipulation of data processed by the researcher. Because in this study the actual data used from the financial statements of pharmaceutical companies contained on the Stock Exchange regarding receivables turnover, as well as cash turnover as well as inventory turnover on profitability $(Y)$. Receivables turnover, cash turnover and inventory turnover on a continuous and positive and significant effect on the profitability of pharmaceutical companies, especially those on the Indonesia Stock Exchange in 2014-2017. The results obtained after testing the hypothesis using the F-test and obtained a significant value $<0.05$. Where these results indicate there is a significant influence, so the hypothesis is very acceptable and proven true.

\section{PENDAHULUAN}

Dalam era globalisasi seperti ini, banyak munculnya berbagai kompetitor baru dari berbagai macam bidang industri perusahaan yang dapat memicu persaingan bisnis apalagi beberapa tahun ini menjadi sangat ketat dan terus menambah kompetitor lainnya, sehingga mengharuskansetiap perusahaan menerapkan sistem manajemen yang harus sesuai dengan prosedur agar dapat mengembangkan dan menjalankan usahanya dengan efektif. Manajemen tersebut digunakan untuk mengatur dan mengontrol kegiatan operasional perusahaan sehingga apa menjadi tujuan dari perusahaan agar dapat tercapai dengan baik. Perusahaan didirikan mempunyai tujuan utama mencari keuntungan yang maksimal dan menjaga kelangsungan operasional serta peningkatan keuntungan pemilik modal atau pemegang saham. Kelangsungan dari hidup perusahaan dipengaruhi oleh beberapa hal, salah satunya adalah profitabilitas. Agar dapat memaksimalkan laba, pimpinan harus perlu mengetahui beberapa faktor yangdapatberpengaruh besar terhadap profitabilitas perusahaan, halini juga dapat ditunjukkan atas laba yang dapat dihasilkan dari penjualan serta pendapataninvestasi.

Menurut Brigham dan Weston (2014:89) profitabilitas adalah hasil akhir dari serangkaian kebijakan serta keputusan manajemen, dimana kebijakan dan keputusan ini menyangkut pada sumber serta penggunaan dana dalam menjalankan operasional perusahaan yang telah terangkum di dalam laporan neraca dan unsurunsur dalam neraca yang ditunjukkan oleh rasio-rasio keuangan. Ada beberapa ukuran yang memungkinkan dipakai untuk mengetahui kondisi profitabilitas pada suatu perusahaan, diantaranya dengan menggunakan rasio tingkat pengembalian aset (Return On Asset).

Pada rasio ini dapat diukur dengan membandingkan dua faktor diantaranya laba bersih dan juga dengan total aktiva, jika semakin tinggi laba bersih terhadap total aktiva maka kondisi ini akan semakin membaik juga bagi perusahaan. Dilihat secara umum rasio profitabilitas dapat dihitung dengan membagi 
laba dengan modal. Bebrapa komponen modal kerja yaitu kas, piutang serta persediaan yang dapat dikelola dengan menggunakan cara yang berbeda guna dapat memaksimalkan laba untuk meningkatkan pertumbuhan perusahaan.

Perusahaan dinyatakan mampu mengelola aset dan modal yang digunakan secara baik dan efektif jika laba yang diperoleh akan semakin besar (Sartono, 2013:95). Perbandingkan laba yang dapat diperoleh satu periode (tahun) dengan jumlah aktiva yang dimiliki perusahaan, maka dapat diketahui besarnya profitabilitas perusahaan tersebut, yang dinyatakan dalam persentase. Dalam peneliti ini, penulis menggunakan rasio ROAsebagai alat ukur profitabilitas pada perusahaan.

Penelitian dilakukan di perusahaan farmasiyangsudah terdaftar dalam BEI Periode 2014 sampai 2017 dengan digunakannya rasio keuangan perputaran piutang, kas dan persediaan serta mengukur rasio profitabilitas.Alasan peneliti mengambil judul inikarena terdapat perbedaan hasil penelitian sebelumnya yang menyatakan berpengaruh sedangkan peneliti yang lainnya menyatakan tidak berpengaruh. Hal tersebut menyimpulkan bahwa penelitian ini belum konsisten yang membuat peneliti ingin menkaji ulang.

\section{Rumusan Masalah}

Dari pemaparan latar belakang di atas, maka yang menjadi permasalahan bagi peneliti dalam penelitian ini adalah:

1. Apakah perputaran piutang berpegaruh serta signifikan terhadap profitabilitas?

2. Apakah perputaran kas berpegaruh serta signifikan terhadap profitabilitas?

3. Apakah perputaran persediaanberpegaruh serta signifikan terhadap profitabilitas?

4. Apakah perputaran piutang, kas danpersediaansecara simultan serta signifikan berpengaruh terhadap profitabilitas?

\section{Tujuan Penelitian}

Berdasarkan rumusan masalah diatas, maka peneliti memiliki tujuan yaitu:

1. Untukmenganalisispengaruh dan signifikansipiutangterhadap profit perusahaan.

2. Untuk menganalisispengaruh dan signifikansikasterhadap profit perusahaan.

3. Untukmenganalisispengaruh dan signifikansipersediaanterhadap profit perusahaan.

4. Untuk menganalisis pengaruh pada perputaran piutang, kas sertapersediaan secara simultan terhadap profit perusahaan.

\section{LANDASAN TEORI}

\section{Profitabilitas (ROA)}

Profitabilitas menunjukkan bagaimana kemampuan perusahaan tersebut dengan seluruh sumber daya yang kemungkinan dimiliki misalnya kegiatan penjualan, arus kas, modal, serta jumlah karyawan dan sebagainyauntuk menghasilkan laba atau profit selama periode tertentu. Sedangkan ROA adalah salah satu bagian Rasio Profitabilitas yang biasadigunakan dalam mengukur atas kemampuan sebuah perusahaanuntuk dapatr menghasilkan laba pada masa lalu sehingga kemudian diproyeksikan dimasa yang kemudain akan datang. Berikut cara menghitung profitabilitas perusahaan:

$$
\text { Return on Asset }=\frac{\text { laba bersih setelah pajak }}{\text { total aktiva }}
$$

\section{Perputaran Piutang}

Lukman Syamsuddin (2015:254) mendefinisikan piutang sebagai transaksi pembelian yang dilakukan secara kredit tetapi yang tidak dibutuhkannya suatu catatan (surat formal) serta tidak perlunya ditandatangani guna menyatakan kewajiban antara pihak pembeli dan pihak penjual. Sedangkan menurut Muslich (2013:109) Piutang dapat terjadi ketika penjualan barang serta jasa apabila dilakukan secara kredit seperti biasanya, yang bertujuan untuk memperbesar nilai penjualan. Berikut perhitungan perputaran piutang:

$$
\text { Perputaran Piutang }=\frac{\text { Penjualan } \text { Kredit }}{\text { Rata }- \text { rata Piutang }}
$$




\section{Perputaran Kas}

Kas diartikan sebagai nilai uang (kontan) yang tersediadidalamperusahaan begitu juga pos-pos lain yang dapat diuangkan dalam jangka pendek guna untuk memenuhi kebutuhan finansialnya. Kas merupakan sebagianunsurdalam modal kerja yang tertinggitingkatanlikuiditasnya. Besaran kas dan kemampuan perusahaan dalam memenuhi kewajiban (jangka pendek) suatu perusahaan berbanding lurus sehingga semakin besar kas maka semakin tinggi pula likuiditasnya. Berikut cara mengghitung perputaran kas suatu perusahaan:

\section{Perputaran Persediaan}

$$
\text { Perputaran Kas }=\frac{\text { Penjualan Bersih }}{\text { Rata }- \text { rata Kas }}
$$

Perputaranpersediaan merupakanberapa banyak persediaan diganti (dijual) dalamsatu periode. Dengan demikian, merupakan tingkat perputaran persediaan berbanding lurus atas tingkat penjualan yangberarti bahwa tingginya tingkat persediaan menunjukkan adanya tingkat penjualan yang tinggi pulapada perusahaan. Berikut juga perputaran persediaan (meningkat) yang tinggi akan meminimalisir tingkat kerugian dan biaya yang dikeluarkan. Berikut cara menghitung perputaran persediaan:

$$
\text { Perputaran Persediaan }=\frac{\text { Harga Pokok Penjualan }}{\text { Rata }- \text { rata Persediaan }}
$$

\section{Penelitian Terdahulu}

Penelitian terdahulu yang menjadi referensi dilakukannya peneitian ini adalah:

1) Arum Puji Tri Lestari (2017) dengan tema yang sama yakni pengaruh perputaran kas, piutang serta persediaan terhadap profitabilitas, hanya saja peneliti ini berfokus pada beberapa perusahaan manufaktur yang telahterdaftar di BEI. Hasil penelitian menunjukkan bahwa:

a) Terdapat pengaruh negatif serta signifikan diantara perputaran kas danprofit perusahaan.

b) Tidak terdapat pengaruh positif serta signifikan antarapersediaan dan profit perusahaan.

c) Terdapat pengaruh positif serta adanya pengaruhdiantara perputaran piutang danprofitperusahaan.

d) Terdapat pengaruh positif serta signifikan antara kas, persediaan, serta piutang berpengaruh simultan terhadap profit perusahaan.

2) Rio Widiasmoro (2017) dengan tema yang sama yaitu pengaruh perputaran kas, piutang serta persediaan terhadap profit dan berfokus pada perusahaan manufaktur. Variabel independen yang terkandung dalam penelitian ini merupakan perputaran kas, persediaan, serta perputaran piutang. Sedangkan variable dependen adalah profitabilitas (ROA).Populasi yang terkandungdi dalam penelitian ini merupkan seluruh perusahaan manufaktur yang telah terdaftar di BEIperiode 2011 - 2014, terdapat total 143 perusahaan.Pengambilan sampel yang terkandung dalam penelitian ini dilakukan dengan menggunakan teknik purposive sampling, yaitu metode pengambilan sampel yang ditetapkan atau ditentukan dengan menggunakan kriteria-kriteria tertentu.Analisis data meggunakan regresi linier berganda, serta uji asumsi klasik, uji t, tidak lupa juga uji F, dan uji koefisien determinasi.

3) Sarjito Surya dkk (2017) dengan tema yang sama yaitu Pengaruh Perputaran Kas, Persediaan Terhadap Profitabilitas. Penelitian ini dilakukan guna untuk mengetahui adanya atau tidak hubungan antara perputaran kas, perputaran persediaan dengan profitabilitas. Penelitian ini menggunakan teknik sampling yang menggabil sampel 8 (delapan perusahaan). Teknikyang digunakan merupakan analisis regresi linearberganda, serta uji simultan dan uji parsial. Variabel terikatya itu profitabilitas, sedangkan variable bebasnya adalah perputaran kas dan juga perputaran persediaan. Hasil penelitian ini dapat menunjukkan bahwaadanya atau tidak pengaruh secara simultan maupun parsial perputaran kas dan juga perputaran persediaan tidak berpengaruh serta signifikan terhadap profitabilitas.

\section{Hipotesis}

Berdasarkan uraian data penelitian yang telah diuraikan pada bagian sebelumnya maka hipotesis yang dikemukakan dalam penelian ini adalah :

$\mathbf{H}_{1}$ : Perputaran Piutang berpengaruh serta signifikan terhadap profit

$\mathbf{H}_{2}$ : Perputaran kas berpengaruh serta signifikan terhadap Profitabilitas

$\mathbf{H}_{3}$ : Perputaran persediaan berpengaruh serta signifikan terhadap Profit 
H4: Perputaran Piutang, kas serta perputaran persediaan secara berkesinambungan (simultan) dapat berpengaruh dan juga signifikan terhadap Profit

\section{Kerangka Konseptual}

Landasan teori dan tinjauan penelitian terdahulu maka dapat dirumuskan kerangka konseptual penelitian pada gambar berikut :

\section{Gambar 1. Kerangka konseptual}

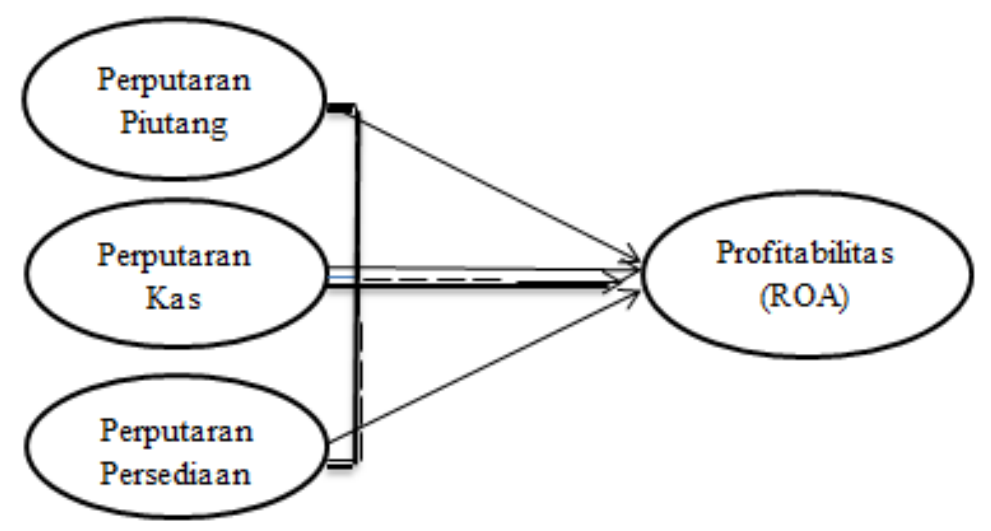

\section{METODOLOGI PENELITIAN}

Dalam penelitian ini rancangan penelitian dimaksudkan untuk mendapatkan data yang tepat sehingga hasil dari penelitian harus dilakukan sesuai dengan prosedur yang sistematis dan jelas. Untuk dapat mencapai tujuan tersebut, maka perlu suatu rancangan penelitian yang merupakan tahap dari proses yang dibutuhkan dalam merencanakan dan melaksanakan penelitian. Dengan hal ini rancangan penelitian dapat disimpulkan padagambar:

Gambar 2. Rancangan Penelitian

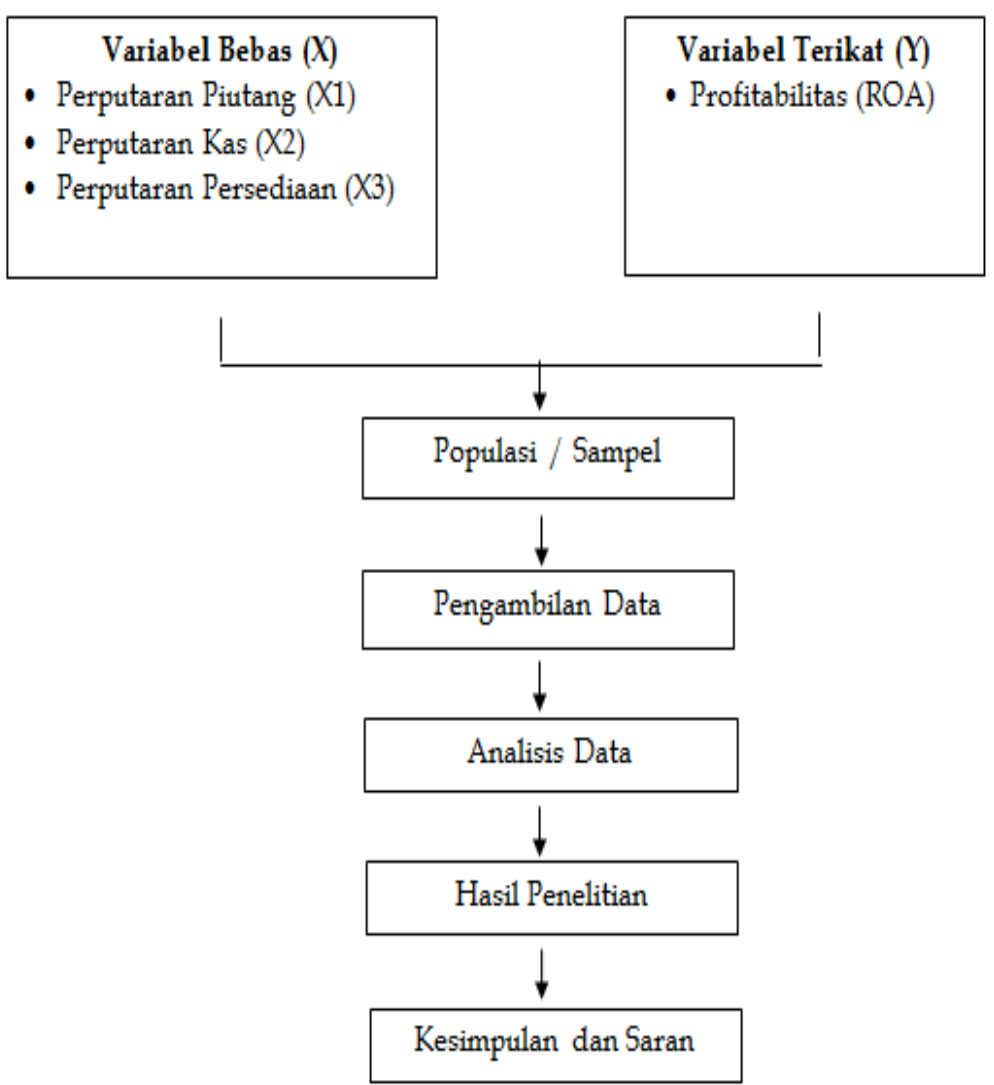




\section{E ISSN 2715-1212}

\section{HASIL DAN PEMBAHASAN}

\section{Uji Normalitas}

One-Sample Kolmogorov-Smirnov Test
\begin{tabular}{|ll|r|}
\hline \multicolumn{1}{|l}{} & $\begin{array}{r}\text { Unstand } \\
\text { ardized } \\
\text { Residua } \\
1\end{array}$ \\
\hline $\mathrm{N}$ & Mean & $0 \mathrm{E}-7$ \\
& & \\
Normal Parameters & a,b & Std. \\
& Deviati & 8,57653 \\
& on & 460 \\
Most Extreme & Absolut &, 185 \\
Differences & e &, 185 \\
& Positive & Negativ \\
Kolmogorov-Smirnov Z &,- 124 \\
Asymp. Sig. (2-tailed) & 1,169 \\
\hline
\end{tabular}

\section{Sumber : Lampiran Uji Asumsi Klasik}

Uji normalitas data dapat digunakan guna menguji apakah adanya kesamaan dalam sebuah variabel dependent, variabel independent, atau kedua keduanya mempunyai distribusi secara baik sertanormal atau tidak, Untuk mempermudah perhitungan akan digunakan software SPSS versi 23.0, sehingga diperoleh output Seperti gambar diatas dan berdasarkan hasil pengujian diperoleh nilai asymp.sig sebesar 0,130 (0,130>0,05). Sehingga mendapat kesimpulan bahwa data yang digunakan di dalam penelitian ini berdistribusi secara normal.

\section{Uji Regresi Linier Berganda}

\section{Uji Regresi Linier Berganda}

\begin{tabular}{|c|c|c|c|c|c|c|}
\hline \multicolumn{7}{|c|}{ Coefficients $^{2}$} \\
\hline \multirow[t]{2}{*}{ Mod } & & \multicolumn{2}{|c|}{ Unstandardized Coefficients } & \multirow{2}{*}{$\begin{array}{c}\begin{array}{c}\text { Standardized } \\
\text { Coefficients }\end{array} \\
\text { Beta } \\
\end{array}$} & \multirow[t]{2}{*}{$\mathrm{t}$} & \multirow[t]{2}{*}{ Sig. } \\
\hline & & $\mathrm{B}$ & Std. Error & & & \\
\hline \multirow{4}{*}{1} & (Constant) & 6,864 & 6,000 & & 1,144 &, 260 \\
\hline & Perputaran Piutang & 10,414 & 3,529 &, 480 & 2,951 &, 006 \\
\hline & Perputaran Kas &,- 082 &, 033 &,- 393 & $-2,487$ &, 018 \\
\hline & Perputaran Persediaan & 2,048 &, 958 &, 330 & 2,137 &, 039 \\
\hline
\end{tabular}

\section{a. Dependent Variable: Profitabilitas \\ Sumber: Lampiran Output SPSSUji Regresi Linier Berganda}

Model regresi liner adalah suatu model yang menggunakan parameter linier (fungsinya tidak selalu berbentuk garis lurus), serta secara kuantitatif bisa digunakan untuk menganalisis pengaruh antar suatu variabel.

Berdasarkan table diatas dapat diketahui model regresinya dari keempat variabel, yaitu:

$$
\mathrm{Y}=6,864+10,414 \mathrm{X} 1-0,082 \mathrm{X} 2+2,048+\mathrm{e}
$$


Berdasarkan hasil persamaan diatas dapat diperoleh dan dijelaskan bahwa makna dari koefisien regresi sebagai berikut:

a) Dari persamaan tersebut, nilai konstanta adalah 6,864. Hal ini dapat menunjukkan bahwa apabilanilai variabel perputaran piutang, kas dan ppersediaan sama dengan nol. maka nilai variabel profitabilitas sebesar 6,864.

b) Koefisien regresi variabel perputaran piutang atau (X1) sebesar 10,414. menunjukkan besar pengaruh variabel perputaran piutang atau (X1) terhadap profitabilitas. Nilai perputaran piutang atau (X1) bertanda positif menunjukkan pengaruh yang searah. Artinya apabila variabel perputaran piutang atau (X1) mengalami kenaikan satu satuan, maka profitabilitas atau (Y) dapat mengalami peningkatan sebesar 10,414.

c) Koefisien regresi variabel perputaran kas atau (X2) sebesar -0,082. Menunjukkan besarnya pengaruh (variable) perputaran kas atau (X2) terhadap profitabilitas. nilai perputaran kas atau (X2) bertanda negtif menunjukkan pengaruh yang berbalik. Artinya apabila variabel perputaran kas atau (X2) mengalami penurunan satu satuan, maka profitabilitas atau (Y) akan mengalami peningkatan sebesar $-0,082$ dan sebaliknya.

d) Koefisien regresi variabel perputaran persediaan atau (X3) sebesar 2,048. menunjukkan besar pengaruh variabel perputaran persediaan atau (X3) terhadap profitabilitas. nilai perputaran persediaan atau (X3) bertanda positif menunjukkan pengaruh yang searah. Artinya apabila variabel perputaran persediaana atau (X3) mengalami kenaikan satu satuan, maka profitabilitas atau (Y) akan mengalami peningkatan sebesar 2,048.

\section{Koefisien Korelasi Dan Determinasi (R2)}

\section{Hasil Analisis Koefisien Determinasi dan Korelasi}

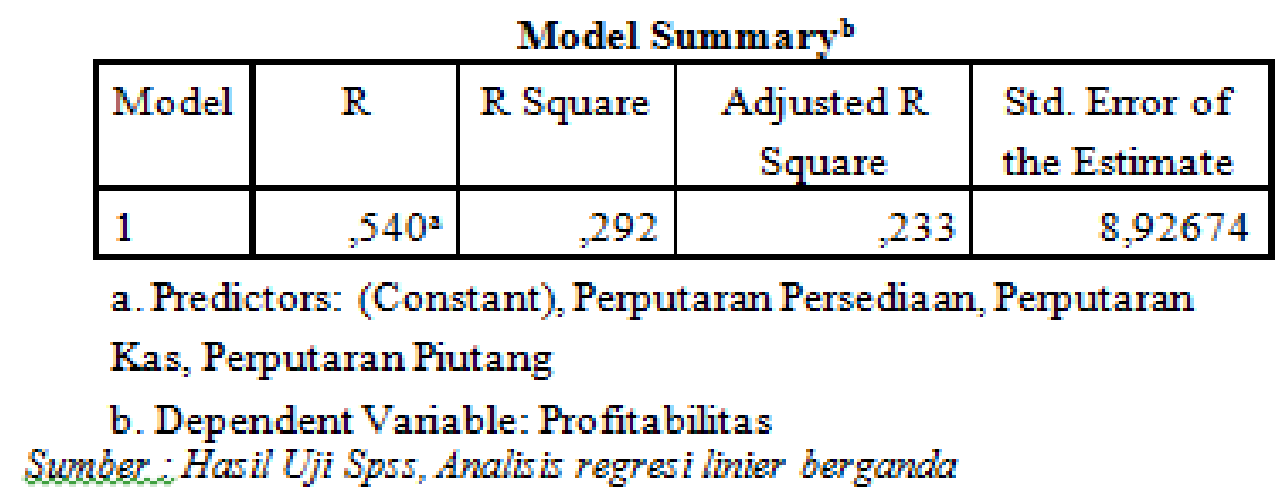

Dari tabel diatas hasil pengolahan data maka dapat disimpulkan bahwa:

a) Nilai korelasi masing-masing variabel bebas dapat dilihat dalam tabel berikut :

Interpretasi Koefisien Korelasi

\begin{tabular}{cc}
\multicolumn{2}{c}{ Interpretasi Koefisien Korelasi } \\
\hline Interval Koefisien Korelasi & Tingkat Hubungan \\
& \\
\hline $0,00-0,199$ & Sangat Rendah \\
$0,20-0,399$ & Rendah \\
$0,40-0,599$ & Sedang \\
$0,60-0,799$ & Kuat \\
$0,80-1,000$ & Sangat kuat
\end{tabular}

Sumber-Sugixone (2014:194)

Berdasarkan analisis yang dapat dilakukan menggunakan regresi linier berganda menggunakan bantuan program stastistik SPSS versi 23,0 didapatkan hasil pada tabel Model Summary yang menunjukkan nilai koefisien korelasi sebesar $R=0,540$ artinya terdapat korelasi positif. Berdasarkan klaster tabel koefisien korelasi pada tabel, maka bisa dinyatakan bahwa terdapat korelasi yang sedang antara variabel X1, X2, X3 dan variabel Y (profitabilitas). 


\section{E ISSN 2715-1212}

b) Analisis yang dilakukan dapat menggunakan regresi linier berganda menggunakan bantuan program stastistik SPSS versi 23,0 diperoleh nilai koefisien determinasi (R-Square) sebesar 0,292. Hal ini menunjukkan variable X1, X2, dan X3dapat mempengaruhivariabel Y (profitabilitas) sebesar 29,2\%, sedangkan $71,8 \%$ dipengaruhi dari variabel bebas lain yang tidak atau belum dimasukkan di dalam penelitian ini .

\section{Pengujian Hipotesis}

\section{Uji T}

Berdasarkan tabel diatas diperoleh:

a) Diperoleh nilai t-hitung variabel perputaran piutang sebesar 2,951 dengan didapatnya nilai signifikan sebesar 0,006.Dimana nilai t-tabel sebesar 2,024 .sehingga t-hitung > t-table yaitu 2,951>2,024 dan nilai signifikan $0,006<0,05$. Dari hasil tersebut bisa dinyatakan hipotesis diterima, yang artinya perputaran piutang (X1) berpengaruh positif dan secara signifikan terhadap profit suatu poerusahaan.

b) Diperoleh nilai t-hitung variabel perputaran kas sebesar -2,487 dengan didapatnya nilai signifikan sebesar 0,018.Dimana nilai t-tabel sebesar -2,024 sehingga t-hitung >t-table yaitu $-2,487>-2,024$ dan nilai signifikan $0,018<0,05$. Dari hasil tersebut bisa dinyatakan hipotesis diterima, yang artinya perputaran kas (X2) berpengaruh positif serta signifikan terhadap profit suatu perusahaan.

c) Diperoleh nilai t-hitung variabel perputaran persediaan sebesar 2,137 dengan didapatnya nilai signifikan sebesar 0,039.Dimana nilai t-tabel sebesar 2,024 .sehingga t-hitung > t-table yaitu 2,137> 2,024 dan nilai signifikan 0,039<0,05. Dari hasil tersebut maka dinyatakan hipotesis diterima, yang artinya perputaran persediaan atau (X3) berpengaruh positif dan secara signifikan terhadap profit perusahaan.

2. Uji F

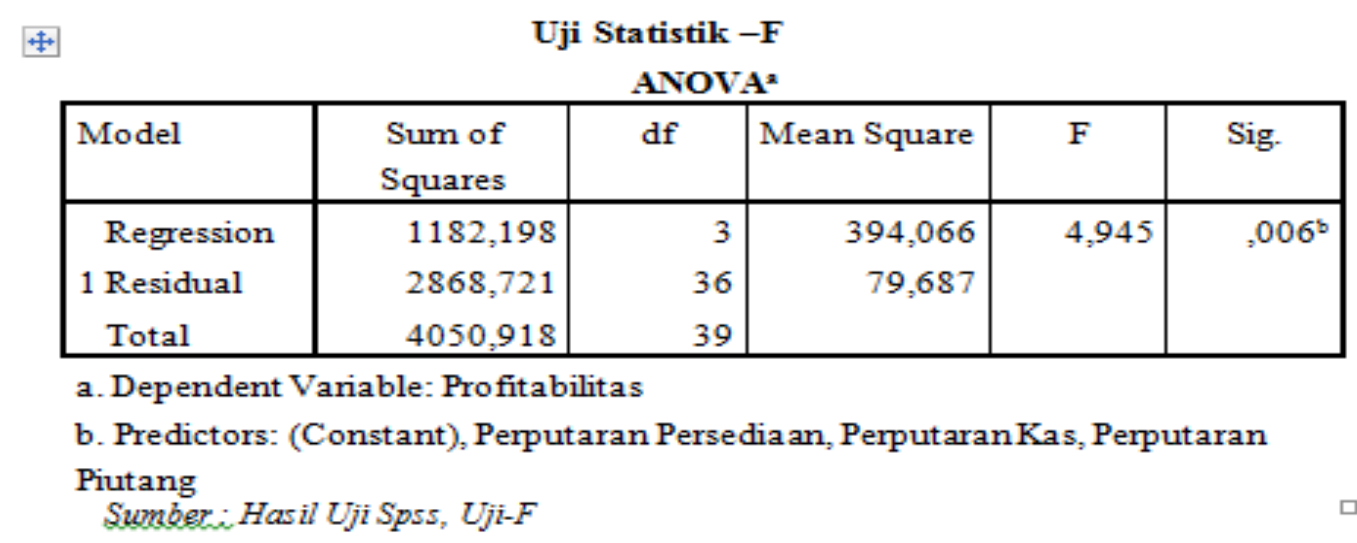

Berdasarkan tabel diatas diperoleh nilai F-hitung sebesar 4,945 dengan didapatnya nilai signifikan sebesar 0,006.Dimana nilai F-tabel sebesar 2,87.sehingga F-hitung > F-table yaitu 4,945 > 2,87 dan nilai signifikan $0,006<0,05$. Dari hasil berikut dapat dinyatakan Hipotesis diterima, yang artinya Perputaran Piutangatau (X1), perputaran kasatau (X2)dan perputaran persediaanatau (X3) simultan (bersama-sama) mempengaruhi secara signifikan terhadap Profit perusahaan yang sudah terdaftar di BEI Tahun 2014-2017.

\section{PEMBAHASAN}

\section{Pengujian Hipotesis 1 dengan menggunakan uji-t}

Hasil pengujian hipotesis 1 menggunakan Uji-t. diperoleh nilai nilai t-hitung variabel perputaran piutang sebesar 2,951 dengan diperolehnyanilai signifikan sebesar 0,006. Dimana nilai t-tabel sebesar 2,024 sehingga t-hitung $>\mathrm{t}$-table yaitu 2,951 $>2,024$ dan nilai signifikan $0,006<0,05$. Dari hasil tersebut maka bisa dinyatakan hipotesis (H1) diterima, yang artinya perputaran piutangatau (X1) berpengaruh positif dan secara signifikan terhadap profitabilitas. Pengaruh perputaran piutang dengan profitabilitas mempunyai nilai positif, yang artinya setiap peningkatan nilai perputaran piutang, akan juga meningkatkan nilai profitabilitas. 


\section{Pengujian Hipotesis 2 dengan menggunakan uji-t}

Hasil pengujian hipotesis 2 menggunakan Uji-t. diperoleh nilai nilai t-hitung variabel perputaran kas sebesar -2,487 dengan diperolehnya nilai signifikan sebesar 0,018.Dimana nilai t-tabel sebesar 2,024.sehingga t-hitung $>\mathrm{t}$-table yaitu 2,487 $>2,024$ dan nilai signifikan $0,018<0,05$. Dari hasil tersebut maka disimpulkan bahwa Hipotesis (H2) diterima, yang artinya perputaran kasatau (X2) berpengaruh negatif serta signifikan, yang artinya setiap penurunan nilai perputaran kas, maka dengan begitu juga akan meningkatkan nilai profitabilitas.

\section{Pengujian Hipotesis 3 dengan menggunakan uji-t}

Hasil pengujian hipotesis 3 menggunakan Uji-t. diperoleh nilai nilai t-hitung variabel perputaran persediaan sebesar 2,137 dengan diperolehnya nilai signifikan sebesar 0,039.Dimana nilai t-tabel sebesar 2,024 sehingga t-hitung > t-table yaitu 2,137 > 2,024 dan nilai signifikan 0,039<0,05. Dari hasil tersebut maka disimpulkanbahwa Hipotesis (H3) diterima yang artinya perputaran persediaan berpengaruh positif serta signifikan terhadap profitabilitas.Pengaruh perputaran persediaan dengan profitabilitas mempunyai nilai positif, yang artinya setiap peningkatan nilai perputaran persediaan, maka dengan begitu juga akan meningkatkan nilai profitabilitas.

\section{Pengujian Hipotesis 4 dengan menggunakan uji-F}

Hasil pengujian hipotesis 4 menggunakan Uji-F. diperoleh nilai F-hitung sebesar 4,945 dengan diperoleh nilai signifikan sebesar 0,006.Dimana nilai F-tabel sebesar 2,87 sehingga F-hitung > F-table yaitu 4,945 > 2,87 dan nilai signifikan 0,006 > 0,05. Dari hasil tersebut maka disimpulkan bahwa Hipotesis (H4) diterima yang artinya Perputaran Piutangatau (X1), perputaran kas atau (X2)dan perputaran persediaan atau (X3) secara simultan (bersama-sama) memiliki pengaruh serta signifikan atasprofitabilitas.. Pengaruh ini memiliki nilai positif yang berarti adanya keterkaitan hubungan antar tiap variabel jadi apabila setiap peningkatan nilai X1, X2, X3, secara simultan (bersama-sama) mempengaruhi peningkatan nilai profitabilitas.

\section{KESIMPULAN DAN SARAN}

\section{Kesimpulan:}

Berdasarkan analisis data dengan mengacu pada tujuan penelitian, hipotesis dan model analisis, maka kesimpulan pada penelitian ini adalah:

1. Perputaran piutang memiliki pengaruh positif $(+)$ serta signifikan atasprofitabilitas perusahaan farmasi yang telah terdaftar di BEI2014-2017. Hasil didapat setelah melakukan. Pengujian hipotesis menggunakan uji-t dan diperolehnilai signifikan $<0,05$. Dimana hasil tersebut menunjukkan terdapat pengaruh signifikan, Sehingga hipotesis dapat diterimaserta terbukti kebenarannya.

2. Perputaran kas memiliki pengaruh negative (-) serta signifikan atas profitabilitas perusahaan farmasi yang telah terdaftar di BEI 2014-2017. Hasil didapat setelah melakukan. Pengujian hipotesis menggunakan uji-t dan diperolehnilai signifikan $<0,05$. Dimana hasil tersebut menunjukkan terdapat pengaruh signifikan, Sehingga hipotesis dapat diterimaserta terbukti kebenarannya.

3. Perputaran persediaan memiliki pengaruh positif $(+)$ serta signifikan atas profitabilitas perusahaan farmasi yang telah terdaftar di BEI tahun 2014-2017. Hasil didapat setelah melakukan. Pengujian hipotesis menggunakan uji-t dan diperolehnilai signifikan $<0,05$. Dimana hasil tersebut menunjukkan terdapat pengaruh signifikan, Sehingga hipotesis dapat diterimaserta terbukti kebenarannya.

4. Perputaran piutang(X1), perputaran kas(X2) dan perputaran persediaan(X3) secara (simultan) bersama sama berpengaruh positif $(+)$ dan signifikan terhadap profitabilitas pada perusahaan farmasi yang sudah terdaftar di BEI tahun 2014-2017. Hasil didapat setelah melakukan. Pengujian hipotesis menggunakan uji-t dan diperolehnilai signifikan < 0,05. Dimana hasil tersebut menunjukkan terdapat pengaruh signifikan, Sehingga hipotesis dapat diterimaserta terbukti kebenarannya.

\section{Saran}

Berdasarkan hasil penelitian dan analisis data yang telah dilakukan, maka saran-saran yang dapat diajukan yang berkaitan dengan masalah yang diteliti adalah sebagai berikut: 


\section{Bagi Perusahaan}

- Sebaiknya perusahaan meningkatkan piutang dengan cara meningkatkan penjualan kredit. Hal ini dikarenakan dengan meningkatnya piutang perusahaan meningkat, dengan demilikian laba perusahaan juga akan ikut meningkat.

- Sebaiknya pihak perusahaan meningkatkan perputaran persediaan. Dengan adanya peningkatan perputaran persediaan, maka laba perusahaan akan ikut meningkat.

2. Bagi Peneliti Lanjutan

- Bagi para peneliti lanjutan, sebaiknya perlu dilakukan penelitian terhadap faktor - faktor lain yang memberikan pengaruh lebih besar terhadap profitabilitas.

\section{DAFTAR PUSTAKA}

Aaker, J. dan Smith A. 2016. Quick, Effective, and Powerful Ways to Use Social Media to Drive Social Change. ISBN 978-0-470-61415-0. Jossey-Bass.

Agus Ristono. 2015. Manajemen Persediaan. Penerbit Graha Ilmu, Yogyakarta.

Ahmad, Komaruddin. 2015. Dasar-Dasar Manajemen Investasi dan Portofolio. Jakarta : PT.Rineka Cipta.

Arikunto, Suharsimi. 2016. Prosedur Penelitian Suatu Pendekatan Praktik. Jakarta : Rineka Cipta

Baridwan, Zaki. (2015). Intermediate Accounting, Edisi Ketujuh, BPFE, Yogyakarta.

Brigham, Eugene.F dan Joel F. Houston. 2014. ManajemenKeuangan. Edisi Ke-21 Buku 2. Jakarta: Erlangga.

Ghozali, Imam. 2014. Aplikasi Analisis Multivariate dengan Program SPSS Edisi Kesembilan. Semarang: Badan Penerbit Universitas Diponegoro.

Husnan, Suad. (2014). Dasar-Dasar Teori Portofolio dan Analisis Sekuritas, AMP YKPN ,Yogyakarta.

Kasmir. 2014. Manajemen Perbankan. Jakarta: Rajawali Pers.

Kieso, Donald, Jerry J, dkk. 2017. Intermediate Accounting edisi IFRS. Jakarta: Erlangga.

Munawir. 2013. Analisa Laporan Keuangan. Yogyakarta : Liberty

Muslich, Mohamad. 2013. Manajemen Keuangan Modern Analisis, Perencanaan dan Kebijaksanaan, Cetakan Keempat. Jakarta: Bumi Aksara.

Pratowo, dwi dan juliaty,2014, analisis laporan keuangan, konsep dan aplikasi, Yogyakarta

R. Agus Sartono. 2013. Manajemen Keuangan Teori dan Aplikasi. Edisi Ke Empat, BPFE, Yogyakarta.

Reeves, James. M., Warren, Carl S., dkk. 2014, Pengantar Akuntansi (Adaptasi Indonesia) Buku I. Jakarta: Salemba Empat.

Riyanto, Bambang. 2014. Dasar-Dasar Pembelanjaan Perusahaan, Edisi Keempat.Yogyakarta: BPFE.

Rudianto. 2013. Pengantar Akuntansi. Jakarta: Penerbit Erlangga.

Sudana, I Made. 2014. Manajemen Keuangan Perusahaan Teori dan Praktek. Jakarta: Erlangga.

Sudjana. (2014). Metode Statistika. Bandung: Transito.

Sugiyono. 2016. Metode Penelitian Pendidikan (Pendekatan Kuantitatif, Kualitatif dan R\&D. Bandung : Alfabeta

Sujarweni, V. Wiratna. 2015. Statistik untuk Bisnis dan Ekonomi. Yogyakarta: Pustaka Baru Press.

Stice, Stice, Skousen. 2014. Akuntansi Keuangan, Buku I Edisi 16. PT Raja Jakarta: Grafindo Persada.

Syamsudin, Lukman. 2015. Manajemen Keuangan Perusahaan. Jakarta: Raja Grafindo Persada.

Tandelilin, Eduardus. 2014. "Portofolio dan Investasi : Teori dan Aplikasi”. Edisi keempat. Yogyakarta : Kanisius. 